\title{
THE EFFECT OF UNAUTHORIZED PRACTICE OF LAW UPON THE ETHICS OF THE LEGAL PROFESSION
}

\author{
Boyle G. Clark*
}

An appreciation of the effect of unauthorized practice of law upon professional ethics and the administration of justice requires an understanding of the instruments and processes by which justice is administered and the functions of a licensed bar in the judicial system. Only by first visualizing the entire system engaged in the administration of justice and the place of the legal profession therein, can one determine fully the consequence of unauthorized practice.

Under the American system of constitutional government, ultimate responsibility for the administration of justice rests upon the judiciary. However, this does not mean either that the administration of justice is limited to formal proceedings in court or that the judges alone bear the burden of determining and protecting the rights of the public. As a matter of fact, formal litigation is but one of the many processes provided for the protection and determination of legal rights. The bar is maintained as an agency of the courts to assist in the administration of justice both within and without the courtroom. The members of the bar are officers of the court without whom the courts cannot function, and without whom the courts would be powerless to discharge their obligation to see that justice is administered fairly not only in the courtroom, but in the field outside the direct supervision of the courts, where the greatest opportunity for miscarriage exists. It is as much the concern of the courts when the administration of justice is thwarted by dishonesty, ignorance, and lack of access to the courts as when the same result is reached by perjury, or tampering with a jury in formal proceedings. To insure to the public adequate protection from dishonesty and incompetence in the pursuit of justice, membership in the bar is limited to those who have proven themselves to be of superior learning and character. To maintain standards of superior ability and conduct the members of the bar are required to conform to a higher standard of conduct than that required of every man.

* LL.B., I906, University of Missouri. Member of the Missouri Bar, practicing in Columbia. President of the Missouri State Bar Association, I93I-r932. General Chairman of the Bar Committees of Missouri, established by the Supreme Court of the state to aid it in exercising its control over the practice of law. Contributor to legal periodicals. 
The standards of conduct required of the members of the bar, and which are so necessary to an even administration of justice, are expressed in the canons of professional ethics. By them the lawyer is required to place his duty to the public and the court above that of private gain. He must cooperate with the courts in administering justice, though it be to his personal detriment and possibly to the detriment of his client. He may be required, without remuneration, to serve as counsel for the indigent in civil or criminal cases where justice would be imperiled, were his cooperation withheld. In the interest of affording free access to the instruments of the administration of justice, he is required by law to preserve the confidence of his client. To avoid the maintenance of costly, unseemly and unnecessary strife he is required to refrain from soliciting or stirring up controversies, even though he might personally profit thereby. To avoid the opportunity for traitorous conduct he must forego the representation of conflicting interests. To prevent the use of his skill, learning and position for immoral purposes, his highest responsibility, above that to his client, is to the courts and to the public. To prevent the commercialization of his office and the exploitation of the processes of justice for profit, he is forbidden to divide his compensation with or lend his services to intermediaries and practice brokers. To insure the faithful performance of these trusts, he is amenable to summary discipline or disbarment. As said by Mr. Justice Cardozo, "Membership in the bar is a privilege burdened with conditions." It is these conditions which make the bar useful in dispensing justice, and distinguish the profession of the law from a trade or business. If these conditions are not complied with, justice is imperiled and the public guarantees are lost.

The Supreme Court of Missouri has recognized the relation of unauthorized practice of law and professional ethics, in its rules creating the Missouri Bar Administration. ${ }^{2}$ The Bar Committees of Missouri are charged with the enforcement of the Canons of Professional Ethics and the suppression of the unauthorized practice of law. In Curry v. Dahlberg, the Missouri Supreme Court announced its policy in this respect, saying: ${ }^{3}$

"This court believes that it has the responsibility and the duty to concern itself both with regard to proper conduct of licensed practitioners and with unlawful practice of law by all others to the end that legal services required by the public, and essential to the administration of justice, will be rendered by those who have been found by investigation to be properly prepared to do so by conforming to strict educational standards, and who demonstrate that they have the character to conform to higher standards of ethical conduct than are ordinarily considered necessary in business relations which do not involve the same fiduciary and confidential relationships. To enforce such standards of ability, knowledge and conduct, it is necessary in the public interest to prevent those who will not or

${ }^{2}$ People ex rel. Karlin v. Culkin, 248 N. Y. $465,470,162$ N. E. 487,489 (1928).

'The Missouri Bar is partially integrated by judicial rule. See Clark, Missouri's Accomplishments and Program for Eliminating the Unlawful Practice of the Law (1936) 22 A. B. A. J. 9.

${ }^{3}$ The quotation is from the opinion denying a motion for rehearing which has not yet been reported. The court, sitting en banc, adopted the opinion of the divisional judge set forth in $110 \mathrm{~S}$. W. (2d) 742 (1937) as the opinion of the court. 
cannot comply with them from engaging in competition for legal work with those who must and do observe them, especially when as here, such employment is obtained by advertising and soliciting rather than by being sought out because of known integrity and ability."

In this setting it is easy to determine the effect of unauthorized practice of law upon professional ethics in the functioning of the judicial processes.

"Unauthorized practice of law," as we use the term, includes not only performance by an unlicensed person, of acts which constitute the practice of law, but also the directly related conduct of intermediaries and practice brokers engaged in controlling the flow of professional employment for profit and, as middlemen, selling the services of lawyers.

With respect to the performance of professional services by laymen or corporations, it is immediately evident that the public and the administration of justice are injuriously affected. The unauthorized practitioner recognizes no obligation to the courts or to the public. His sole object is personal gain. Absent are the guarantees of superior skill, learning and character when he is employed. Likewise absent is the deterrent against dishonesty, disloyalty, and perversion of the laws present in the existence and enforcement of the code of professional ethics when the lawyer acts. Solicitation and salesmanship dictate the flow of employment rather than integrity and ability. The administration of justice is placed in the hands of the usurper, and the corporate entity responsible to its stockholders only. The enforcible morals of the commercial practitioner of law are the enforcible criminal laws. So in this case the administration of justice and the public interest are subordinated to the pursuit of the dollar.

The demoralizing effect of the unauthorized practice of law upon the adherence by the bar to its code of ethics is no longer subject to dispute. The results which have been produced are a matter of history, susceptible of proof. Furthermore the field of demoralization is continually widening as the unauthorized practitioners extend the scope of their operations.

The unethical conduct of lawyers which has been occasioned by the unauthorized practitioner can be roughly divided into three general classes: $(r)$ misconduct caused by competition of the unauthorized practitioner, (2) misconduct caused by dependency upon the unauthorized practitioner, (3) misconduct caused by the example of the unauthorized practitioner.

Solicitation by advertising for professional employment is condemned by the canons of ethics of the legal profession. This conduct is condemned because it injuriously affects the public interest and the administration of justice. If the public interest is to be served professional employment should be based upon known integrity, skill and ability, rather than industrious solicitation and advertising. To prevent an unseemly scramble for professional employment among the members of the bar, the rule against solicitation and advertising was evolved. This rule works 
well so long as those unlicensed are forbidden to compete with the lawyer in the rendition of legal services.

However, the unauthorized practitioner has taken advantage of the professional restraint against solicitation and advertising and proceeded to divert from the members of the bar a large portion of the legal practice. By his code of ethics, the lawyer is forbidden to protect his field of employment. Nevertheless all lawyers are not willing to give up their field without a fight. Consequently, a considerable part of the bar, preferring to remain independent of the control of the unauthorized practitioner, meets solicitation with solicitation, advertising with advertising, practice garnering devices with practice garnering devices. The independent insurance adjustment agency for the insurer finds itself arrayed against the lawyer-devised and controlled claimants' adjustment agency. The claim agent begins to meet the lawyer's runner at the bedside of the injured. Judicial notice of this development was taken by a dissenting judge in the Wisconsin case of Rubin $v$. State: ${ }^{4}$

"This often resulted in claim agents of the corporations following the injured person to the bedside and wrongfully imposing upon him. To overcome this advantage of the large industrial concerns, some lawyers found it to their advantage and the advantage of their clients to meet the claim agent on his own ground."

And so the competition rages between the lawyer who is not content to see his practice stolen by outlaws, and the unauthorized practitioner who finds the practice of law a lucrative and easily entered field. The public, interested in securing a fair and dignified administration of justice and a high quality of legal services, suffers most from this competition.

An even more reprehensible class of misconduct by members of the bar has been engendered by the practices of the unauthorized practitioner. The racketeering law list, the practice broker, the illegal collection agency, the automobile service association, the independent adjuster, the corporate practitioner of the law, have, by securing control of the flow of professional employment, destroyed the independence of the lawyers with whom they deal. These intermediaries have attained a degree of control over the legal profession that minimizes the authority of the courts. This control is based upon the ability to exert upon the lawyer economic pressure and thereby force obedience.

To be specific, the racketeering selected law list solicits large blocks of legal practice. This it practically sells at auction to the member of the bar willing to pay the highest price. ${ }^{5}$ It induces further gross breaches of the canons of ethics on the

' 194 Wisc. 207,216 , at 226,216 N. W. 513,517 , at 521 (1927).

The Missouri investigation of the conduct of law lists disclosed the following facts (among others): That the price charged for representation in "selected lists" was based upon the amount of professional employment produced by the list for the individual listee. That this price was many times the cost of publication plus a good profit to the publisher. That the "selected list" publishers generally attempt to keep a record of items forwarded to the subscriber lawyer over the list and to fix the fee for list representation upon the basis of professional employment produced. That the "selected lists" by initiating an unseemly scramble among lawyers for list representation, by engaging in the barter, sale, and auction of professional employment induce gross breaches in the Canons of Ethics, commercialize the practice of law, 
part of lawyers by maintaining private disciplinary agencies which dictate to the lawyer what business he shall handle and how he shall handle it. In many cases the law lists require the lawyers receiving their business to conduct themselves in a manner contrary to the letter and spirit of the lawyer's code of ethics. Instead of an officer of the court, a lawyer becomes an agent and subject of the unlicensed commercial intermediary.

The same situation obtains in the case of the independent adjustment agency, and the automobile service association, both of which are corporate practitioners of law. In some cases the dependency is direct and the lawyer is merely an employee whose service is being sold by his employer, as a middleman. In other cases the dependency is indirect and the lawyer, though ostensibly an independent practitioner, is in truth but the supplicant beneficiary of the interests that control the course of his professional employment. Dominance of the bar by those who possess a commercial viewpoint produces a conflict between the morals of the market place and the idealistic code of professional ethics. The lawyer no longer chooses the cases which he will bring or determines the manner of their presentation. The lawyer no longer is able to refuse to descend to the practices which breed the miscarriage of justice, nor to follow the dictates of his professional conscience, but lives by the conscience of his commercial mentor. And there is yet to be found the unauthorized practitioner who recognizes the lawyer's duty as expressed in Canon $32 .^{6}$ All this flows from the human susceptibility to economic pressure. While it may be untrue that the love of money is the root of all evil, it must be admitted that the need of money is the root of much evil.

Finally, there is another class of misconduct caused by the example set by the unauthorized practitioner. Members of the bar, observing the scene, discover the wealth which may be gained by exploiting the administration of justice. They ob-

demoralize the field of practice invaded, and create an example which lowers the standard of professional conduct in other fields. That the "selected lists" and their allied intermediaries not only solicit legal practice, but purchase and sell between themselves the control of blocks of items to be forwarded in the furtherance of their agreement to "deliver the goods" to their lawyer subscribers. It is the subscribing lawyer who actually finances these operations.

These facts were developed in the Missouri hearing from the testimony of law list publishers and subscribers alone. The record is filed in the Supreme Court of Missouri, and is available for public inspection.

'Canon 32. The Lawyer's Duty in Its Last Analysis. "No client, corporate or individual, however powerful, nor any cause, civil or political, however important, is entitled to receive nor should any lawyer render any service or advice involving disloyalty to the law whose ministers we are, or disrespect of the judicial office, which we are bound to uphold, or corruption of any person or persons exercising a public office or private trust, or deception or betrayal of the public. When rendering any such improper service or advice, the lawyer invites and merits stern and just condemnation. Correspondingly, he advances the honor of his profession and the best interests of his client when he renders service or gives advice tending to impress upon the client and his undertaking exact compliance with the strictest principles of moral law. He must also observe and advise his client to observe the statute law, though until a statute shall have been construed and interpreted by competent adjudication, he is free and is entitled to advise as to its validity and as to what he conscientiously believes to be its just meaning and extent. But above all a lawyer will find his highest honor in a deserved reputation for fidelity to private trust and to public duty, as an honest man and as a patriot and loyal citizen." 
serve that the public is not quick to become inflamed at commercialization of the practice of law. They learn that undivided loyalty to the courts is not advantageous from a pecuniary standpoint. A professional conscience is suddenly made to appear to be a liability rather than an asset. Under these circumstances it is not strange that a countless number of lawyers yield to the temptation of commercialization, debase their calling and descend to the practices of the unauthorized practitioner, contrary to their own code of ethics.

Commericalization of the bar, loss of the lawyer's independence and lowering of the standards of conduct so loudly bewailed and lamented at bar association meetings has a definite origin.

Cognizance of these conditions was taken by the Supreme Court of Rhode Island. In Rhode Island Bar Association v. Automobile Service Association the court said: ${ }^{7}$

"Under our system of law the most effective guaranty of equal justice to all in the commonwealth is a competent and learned bar composed of men of high personal character who govern their professional conduct at all times by the well-known and generally accepted canons of legal ethics. The lack of such a bar, or the coexistence with it of an array of individuals or groups operating under deceptive devices and catch names to mislead the public into the belief that they are intrusting their causes to those learned in the law and competent to serve them, would inevitably result in a deprivation of justice to many in the state. In such an atmosphere, there would be a strong tendency for the bar to sink to the level of its unauthorized and unqualified competitors. (Italics added.)

"It is our duty to prevent this unfortunate and evil event whenever it threatens. This court is the agent of the people in the administration of justice in this state and has been vested with ample powers to vindicate its authority in this department of the people's government. It would be recreant to the great trust reposed in it if it did not guard every agency by which justice is administered. To safeguard the practice of the law, which touches so intimately the administration of justice, and to promote the welfare of the people, whose ministers we are, this court has ordained certain standards of character and education as a prerequisite to admission to the bar. These standards are high, as indeed they bught to be; and there is constant pressure to elevate them still higher, all to the end that the people may be assured the best possible service in the dispatch of their legal business."

Daily, in our disciplinary work in Missouri, we find evidence of the demoralizing effect of the unauthorized practice upon the bar. ${ }^{8}$ And the statements made here are

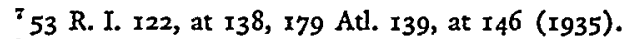

${ }^{8}$ Upon promulgation by the Supreme Court of Missouri of the rules creating the Missouri Bar Administration, we conceived it to be our primary duty to enforce the rules of professional conduct. Beforc undertaking the suppression of the unauthorized practice of law, a vigorous disciplinary campaign was instituted and is being prosecuted at this time. In the three years under the rules, forty-eight disciplinary actions have been instituted against members of the Missouri Bar. In eleven of these cases disbarment was finally ordered. One was dismissed by the court; fifteen suspensions were ordered; two offenders were punished by reprimand administered in open court. Three actions are pending upon reports of the commissioners hearing them; in these three cases, disbarment has been recommended by the commissioner. The remaining sixteen of these actions are pending. Some have been tried and submitted to the commissioner or court and others are coming up for trial in the usual course.

These figures represent only actions instituted in courts of record after preliminary hearings bcforc the Committees. A large number of complaints have been received by the Committes and investigated 
not theories or imagination but the relation of facts which have been judicially found by the bar administration of Missouri. Specific examples abound. It is no longer a question of what the conditions are. The question confronting the public today is what is being done about it. In Missouri we have cleaned our own house and are now engaged in abolishing the unauthorized practitioner. So far we have been successful and are determined to finish the work. We hope never to see the day when the practice of law is again transformed from a profession into a business.

Criminal, dishonest service, is never cheap, no matter what the ostensible price. Justice cannot be bought and sold. It can be secured only through competent, loyal public officers of the highest character. If the unauthorized practitioner is not suppressed, the judiciary will find itself unable to command its own officers, and unable to discharge its constitutional obligations to provide for the administration of justice.

privately. Some of these complaints are still pending before the Committees, others have been dismissed for lack of merit.

A good percentage of the twenty-nine cases finally terminated were disposed of by written opinion of one of the appellate courts of Missouri. Anyone interested in the work of the Missouri Bar Administration may find these opinions in the Missouri Reports and the Southwestern Reporter for the years I935-1938.

No program for the suppression of the unauthorized practice of law will be well received unless the Bar first makes an honest endeavor to clean its own house. This cardinal principle constitutes an essential feature of the Missouri Plan. 